\title{
Ectrodactyly in sisters and half sisters
}

\author{
M H MUFTI* AND S K WOOD $\dagger$ \\ From the Department of Orthopaedics, King Khalid University Hospital, Riyadh, Saudi Arabia.
}

SUMmARY An extended family is described in which four sisters and half sisters presented with $\vec{\circ}$ ectrodactyly. Two of the sisters had associated agenesis of the tibiae. The paper describes the्ట malformations and discusses the management and possible genetic inheritance involved. A autosomal recessive gene seems likely to be the mode of inheritance.

Cleft hand was first described by Paré in $1575 .^{1}$ Historically, other cases were reported by Martens in $1804,{ }^{2}$ Saint Hilaire in $1832,{ }^{3}$ and Kummel in $1895 .{ }^{4}$ The malformation "is characterised by a paraxial or axial longitudinal terminal deficiency of rays usually associated with syndactyly". 5

The first cases of affected children from normal parents were reported by Pott in $1884 .{ }^{6}$ Pearson $^{7}$ first proved dominant inheritance and Fetscher, ${ }^{8}$ and later Popenoe, ${ }^{9}$ suggested that recessive inheritance could occur. Barsky ${ }^{10}$ believed that even typical cases occur sporadically. Birch-Jensen ${ }^{11}$ calculated the incidence of typical split hand as 1 in 90000 births and of atypical split hand, as defined by Lange, ${ }^{12}$ as 1 in 150000 births.

\section{Case reports}

In the family reported here the father is married to two wives, his first cousin and another woman, not known to be related (fig 1 ). The family presented at an Orthopaedic Clinic at King Khalid University Hospital, Riyadh, because the father was worried that the two year old daughter (II.9) was unable to walk because of her leg anomalies. On questioning and examination, four daughters, two from each

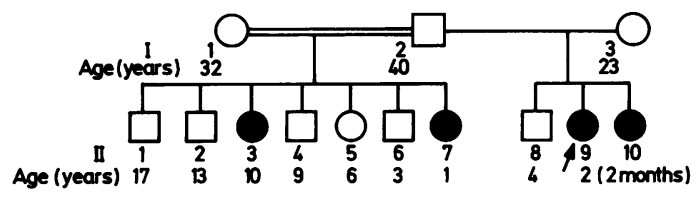

FIG 1 Pedigree of the extended family.

Present addresses: *Department of Orthopaedics, Security Forces Hospital. PO Box 7838, Riyadh 11472, Saudi Arabia. †Orthopaedic Unit, Southampton General Hospital, Southampton SO9 4 XY.

Received for publication 18 April 1984.

Revised version accepted for publication 2 January 1986. wife, were identified as having single or multiple congenital malformations in their extremities. $\mathrm{A} P$ were normal term deliveries. Six normal children of the marriages, the three parents, and all other relatives were normal on clinical examination.

CASE 1

Case 1 (II.3) was 10 years old and had four digit hands (fig 2). The right hand had a thumb and inde? finger on the radial side and on the ulnar side of the cleft a ring and little finger showing partial sym dactyly; the middle finger was absent. $X$ ray showe a small metacarpal bone on the radial side of the cleft. The skeleton of the ulnar side of the cle showed a small malformed metacarpal adjacent to the cleft with a broad malformed metacarpal sup porting the ring and little fingers. The proximal pat of the proximal phalanges of these fingers were joined, but distally the phalanges were separated, were the intermediate and distal phalanges.

The left hand had a thumb and index finger which were normal. On the ulnar side of the hand, there was a normal little finger. The ring and middle finger showed almost complete syndactyly with the middle finger much shortened. The $x$ ray of this hang showed that the middle and ring fingers had separate. slightly malformed metacarpals, but the proximat phalanx of the middle finger lay horizontally and was fused to the short proximal phalanx of the ring finger. There was a common broad intermediate phalanx which was bifid distally. The distal phalan of the ring finger showed a normal basal epiphysis but this was absent in the rudimentary middle finge

\section{CASE 2}

Case 2 (II.7) was one year old. She had a two digit right hand and a four digit left hand with a thum and three other fingers (fig 3 ). $X$ ray of the riglif hand showed that the radial digit was a thumb, whife 

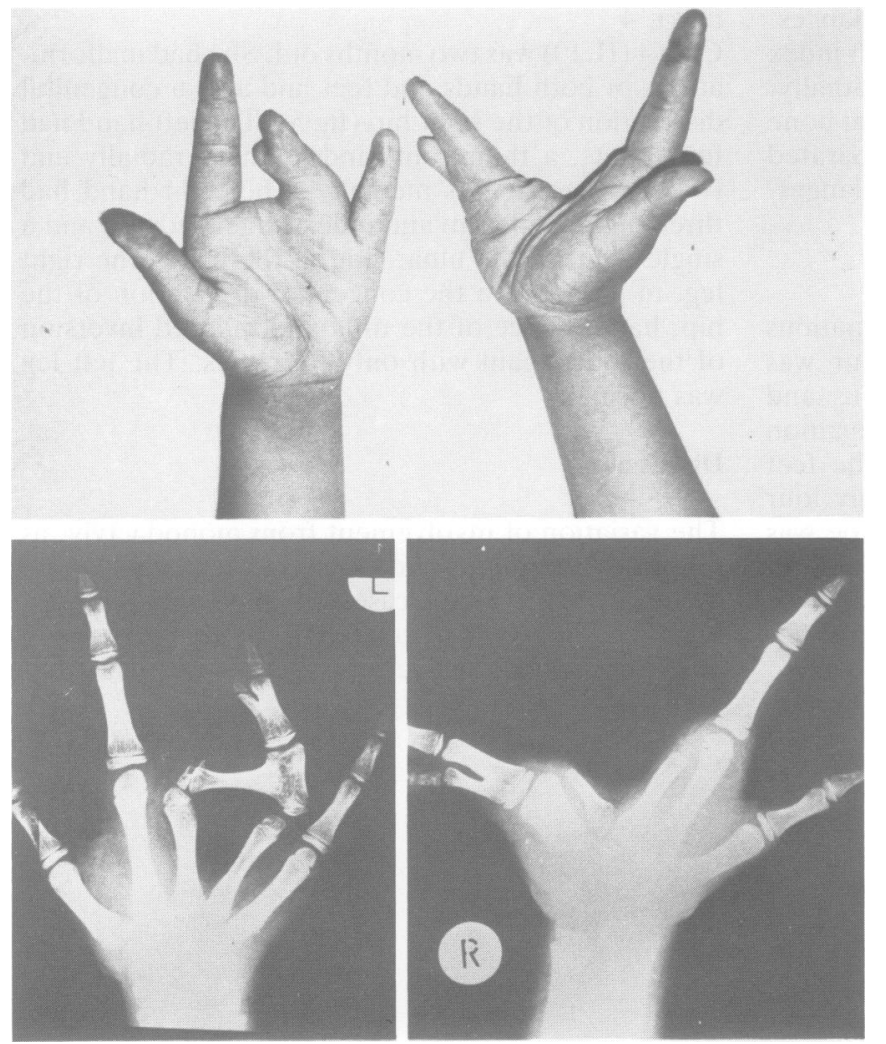

FIG 2 Clinical and radiological appearance of both hands of case 1 (II.3).

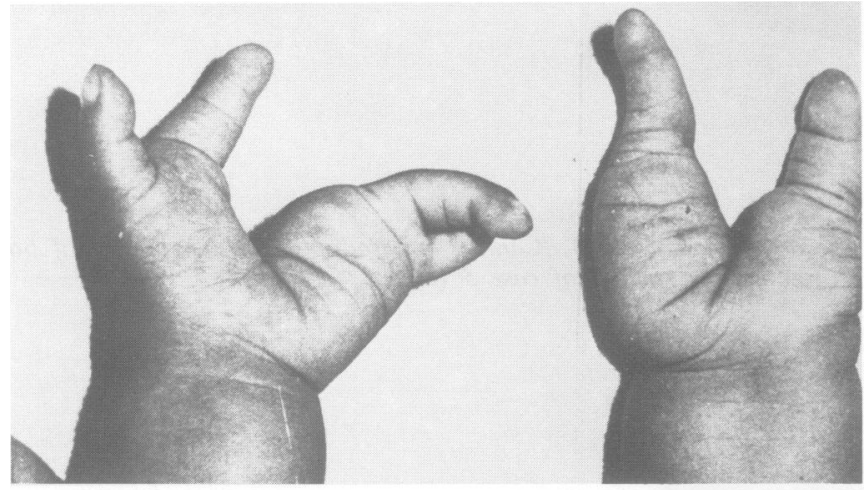

FIG 3 Clinical and radiological appearance of both hands of case 2 (II.7)
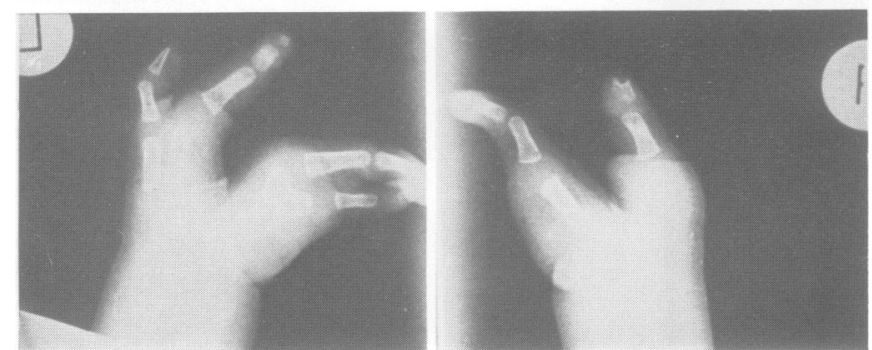
the ulnar digit had a metacarpal and three phalanges. $X$ ray of the left hand showed a thumb and an index finger with a normal complement of bones radially. On the ulnar side of the cleft was a metacarpal bone with a fused base and shaft, but which separated distally to bear two digits each with three phalanges.

\section{CASE 3}

Case 3 (II.9) is two years old. She had malformations in both lower limbs (fig 4). The left femur was shorter than the right and there were varus and flexion deformities of both knees with subluxation of the knee joints. Both legs were thin. The feet showed metatarsus varus and there were only four toes on each foot, but on the right the big toe was bifid distally. The hands were normal. $X$ ray of both legs showed the left femur to be short. Both tibiae were absent so there was no knee joint on either side. Each foot had only four rays.
CASE 4

Case 4 (II.10) was two months old. She had malform- $\overrightarrow{\vec{F}}$ ations of both hands and feet and also a congenital $\stackrel{\rho}{?}$ dislocation of the right hip (fig 5). The left hand had four digits, a thumb and index finger radially and $\overline{\bar{c}}$ two separate fingers medially. The right hand had $\vec{\nabla}$ three digits, a thumb and index finger radially and $a \propto$ single digit on the ulnar side of the cleft. The right leg, in addition to the congenital dislocation of the $\overrightarrow{0}$ hip, had absence of the tibia and marked inversion: of the foot, again with only four toes. The left leg was normal.

\section{Discussion}

The variation of involvement from monodactyly, as $\stackrel{\vec{\sim}}{\text { to }}$ reported by Bujdoso and Lenz, ${ }^{13}$ to syndactyly only, $N$ as occurred in many cases of Scott's pedigree, ${ }^{14}$ 을 seems most likely to be related to variable expression of the genetic anomaly.
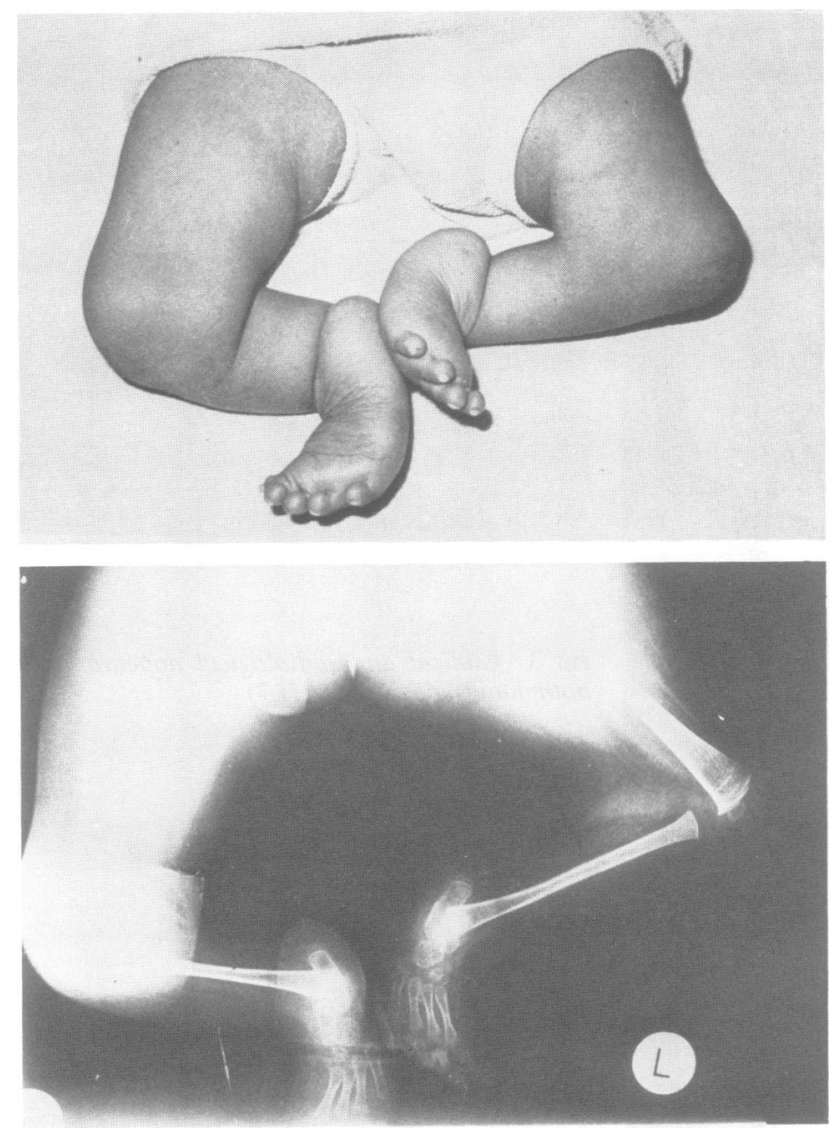

FIG 4 Clinical and radiological appearance of bô̆h legs of case 3 (II.9). 

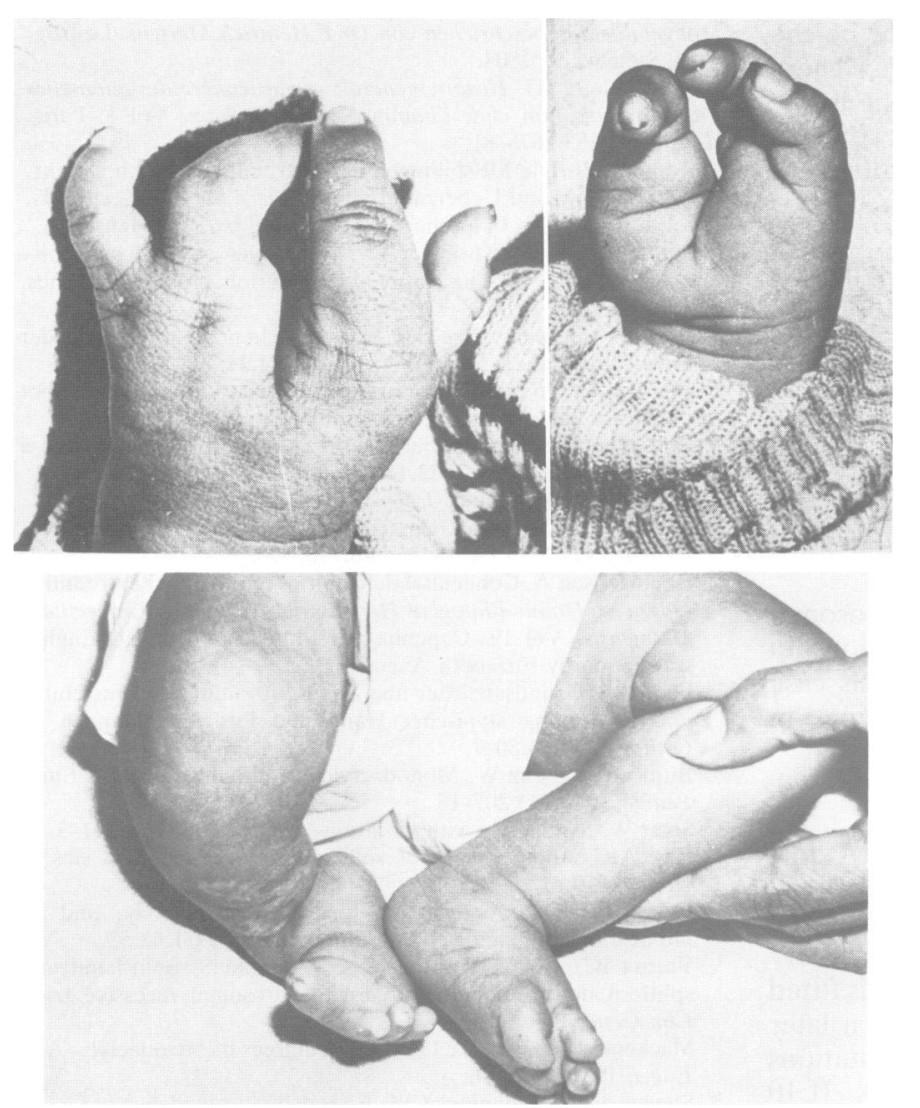

FIG 5 Clinical appearance of both hands and legs of case 4 (II.10).
Ray ${ }^{15}$ and Freire-Maia ${ }^{16}$ reported two pedigrees where cousin marriages resulted in ectrodactyly in the offspring. It seems clear that this was due to an autosomal recessive gene carried by both parents. Verma et al $^{17}$ reported another such pedigree with two first cousin marriages resulting in ectrodactyly in the offspring. Again, it was suggested that an autosomal recessive gene present in both parents was responsible.

The large pedigrees reported by MacKenzie and Penrose, ${ }^{18}$ Stevenson and Jennings, ${ }^{19}$ Scott, ${ }^{14}$ and Khosrovani ${ }^{20}$ all showed autosomal dominant inheritance with complete penetrance. In all there is variable expression and in the pedigree of Scott and Khosrovani ${ }^{20}$ skipping of generations occurred. In both these pedigrees there was no suggestion that the skipping of generations could be due to recessive inheritance.

In pedigree $\mathrm{B}$ of MacKenzie and Penrose,$^{18}$ it seems likely that germinal mosaicism occurred, leading to the usual dominant inheritance. The pedigree reported by Bailey ${ }^{21}$ also suggests that germinal mosaicism could be present in generation I, continuing in generation II, and then producing a regular pattern of dominant inheritance from generation III onwards. Auerbach ${ }^{22}$ suggested the same explanation for the pedigree of Graham and Badgeley, ${ }^{23}$ but Vogel $^{24}$ argued that the malformations were different and the inheritance not due to a single gene. David ${ }^{25}$ reported three families in which germinal mosaicism seemed the most likely explanation of the origin of the malformation.

In the present family, II.3 and II.7 were offspring of a known consanguineous union. Both girls had ectrodactyly of the upper limbs. The malformation accords well with the Birch-Jensen type I 'typical split hand'. II. 9 and II.10 were offspring of the second marriage where there was no known consanguinity. II. 9 had normal hands but multiple malformations in the legs and feet. II.10 had type I hands and also lower limb anomalies.

There are four possible modes of inheritance in 
this pedigree. (1) The malformations could be the result of germinal mosaicism in the father. (2) There could be non-penetrance of a dominant gene in the father. (3) There could be a 'delayed' or two stage mutation with a premutation present in the father. (4) The malformation could be the result of a recessive gene with both wives being heterozygous.

1,2 , and 3 are autosomal dominant types of inheritance and carry a considerable risk of malformations occurring in the next generation. With no known relatives with ectrodactyly, lack of penetrance as an explanation is unlikley and the possibility of a two stage mutation seems unnecessarily complicated to explain the facts. Germinal mosaicism in the father is a possibility and, if the malformation persists in the next generation, will be the most plausible answer.

The most probable explanation is autosomal recessive inheritance with a blood relationship between the husband and both wives. In this case there is little risk of ectrodactyly appearing in generation III.

\section{ORTHOPAEDIC MANAGEMENT}

This family presented at an Orthopaedic Clinic because of the problems with the lower limbs of II.9. The ectrodactyly of the upper limbs in the children was not considered to be a problem requiring surgery by the parents or the eldest child, II.3. II.9 was fitted with prostheses to develop her balance. At a later stage it may be appropriate to carry out amputations to allow the use of better fitting prostheses. II.10 underwent manipulation to reduce the congenital dislocation of the right hip, but again because of the distal deformities she will require a prosthesis when she reaches the age of walking.

The authors wish to acknowledge the helpful advice of $\operatorname{Dr} N$ R Dennis of Southampton University Medical School in the preparation of this paper.

\section{References}

' Paré A. Les oeuvres de M Ambroise Paré. Paris: Gabriel Buon, $1575 ; 815-8$.

2 Martens FH. Uber eine sehr complexierte Hasenscharte oder einen sogenannten Wolfsrachen, mit einer an demselben Subjekte befindlichen merkwurdigen Misstaltung der Hande und Fusse. In: Operirt von Dr Johann Gottlob Echoldt, abgebildetund beschrieben von Dr F Heinrich Martens. Leipzig $\stackrel{\overparen{\Phi}}{+}$ EF Steinacker, 1804.

${ }^{3}$ Saint-Hilaire IG. Histoire generale et particulière des anomaliesos? de l'organisation chex l'homme et les animaux. Vol 1. Pariso Balliere, 1832:676-81.

${ }^{4}$ Kummel W. Die Missbildugen der Extremitaten durch Defekt $\frac{\overline{\bar{N}}}{\bar{\sigma}}$ Verwachsung und Ueberzahl. In: Biblioteca Medica. Section E vol 3, Kassel: Th G Fischer, 1895 (quoted by Birch-Jensen ${ }^{11}$ ). Ф

"Temtamy SA, McKusick VA. The genetics of hand malform ations. New York: The National Foundation- March of Dimeses Birth Defects 1976:53-71.

6 Pott R. Ein Beitrag zu den Symmetrichen Missbildungen der Finger und Zehen. Jb Kinderheilkd 1884;21:392-4.

${ }^{7}$ Pearson K. On inheritance of the deformity known as split foof or lobster claw. Biometrika 1908;6:69-79.

${ }^{8}$ Fetscher R. Einstammbaum mit Spalthand. Arch RassanGesellschaft Biologie 1922;14:176-9.

9 Popenoe P. Split hand. J Hered 1937;28:174-6.

10 Barsky AJ. Cleft hand: classification, incidence and treatment J Bone Joint Surg (Am) 1964;46:1707-20.

$"$ Birch-Jensen A. Congenital deformities of the upper extremitie N Opera ex Domo Biologiae Hereditariae Humanae Universitatio Hafniensis. Vol 19. Copenhagen: Munksgaard, 1949 (EnglisR translation by Elizabeth Aageson).

12 Lange M. Grundsatzlicher uber die Beurteilung der Entstehun und Bewertung atypischer Hand und Fussmissbildungen. $Z$. Orthop 1937;66:80-7.

13 Bujdoso G, Lenz W. Monodactylous splithand-splitfoot. Eur $\overrightarrow{\mathrm{O}}$ Pediatr 1980;133:207-15.

${ }_{14}$ Scott W. Syndactyly with variations. J Hered 1933;24:241-3.

15 Ray AK. Another case of splitfoot mutation in two sibs. Hered 1970;61:169.

${ }^{16}$ Freire-Maia A. A recessive form of ectrodactyly, and implications in genetic counselling. J Hered 1971;62:53.

17 Verma IC, Joseph R, Bhargava S, Mehta S. Split-hand an splitfoot deformity inherited as an autosomal recessive traie Clin Genet 1976;9:8-14.

18 Mackenzie HJ, Penrose LS. Two pedigrees of ectrodactyly. An Eugen 1951;16:88-96.

${ }^{19}$ Stevenson AC, Jennings CM. Ectrodactyly-evidence in favou? of a disturbed segregation in the offspring of affected maleș Ann Hum Genet 1960;24:89-96.

20) Khosrovani H. Malformations des mains et des pieds (ectro dactylie à travers cinq générations successive dans une grandé famille Vaudoise. J Genet Hum 1959;8:1-60.

21 Bailey Sd'A. A pedigree of syndactylism. J Hered 1938;29:467 $\$$.

22 Auerbach C. A possible case of delayed mutation in man. Ang Hum Genet 1956;20:266-9.

23 Graham JB, Badgeley CE. Split hand with unusual complications. Am J Hum Genet 1955;7:44-50.

24 Vogel F, Verzogerte Mutation beim Menschen? Einige Kritischs Bermerkungen zu Ch Auerbach's Arbeit (1956). Ann Hun Genet 1958:22:132-7.

25 David TJ. Dominant ectrodactyly and possible germinaf mosaicism. J Med Genet 1972;9:316-20.

Correspondence and requests for reprints to $\mathrm{Mr} \mathrm{S}$ Wood, FRCS, Orthopaedic Unit, Room CF86 Southampton General Hospital, Southampton SO $4 X Y$. 